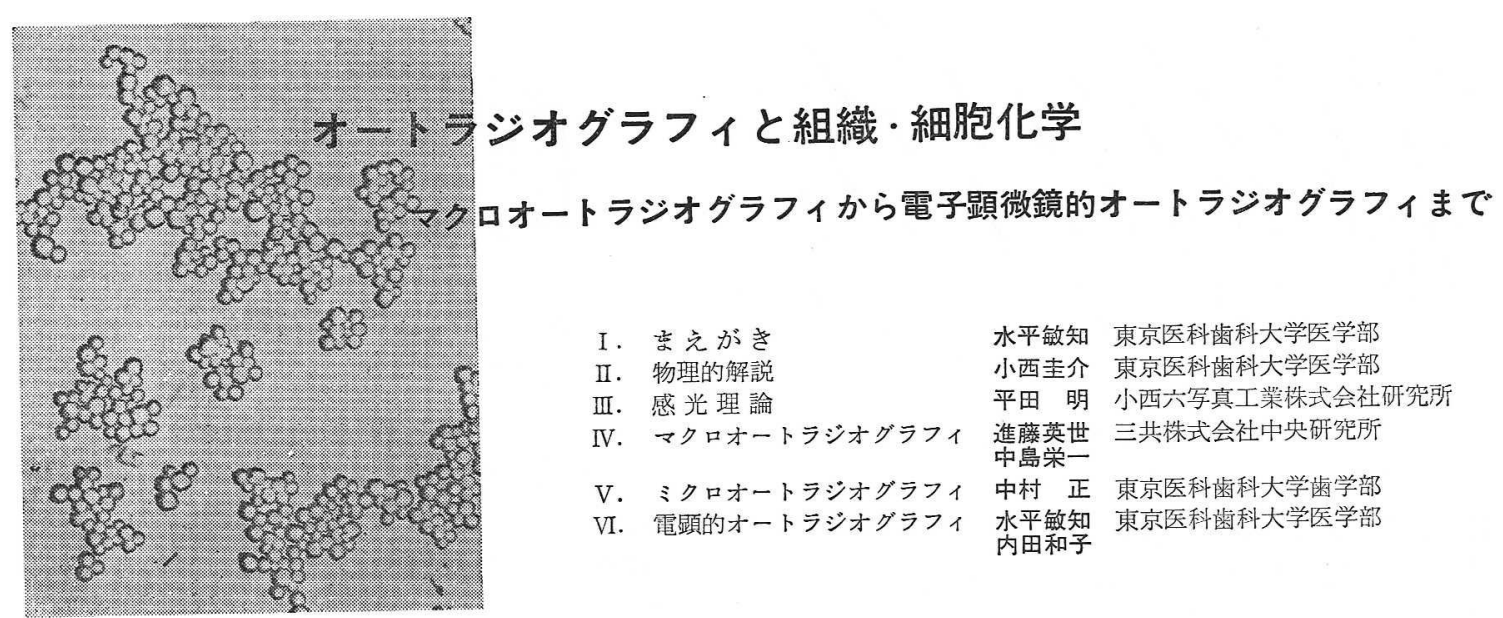

\title{
III. オートラジオグラフィのための感光の理論
}

平田明 小西六写真工業株式会社

ネ・ートラジオグラフィとは，一、に言うと標本中の放 射性网位元素の分布を, それから出る放射線の感光作用 によって，標本に密着させた写真乳剂膜に直接記録させ る方法である。もとより分布像を記録する材料は写真乳 剤膜に限ったことではなく, 放射線によって変化を起こ し，その変化が何らかの手段で観察できれば，これもま たオートラジオグラフィと言ってもよいであろう。しか しながら，写真乳剤には後述するところの現像というき わめて勝れた増幅処理が利用できることもあって, 現在 のところこれ優る感度の材料がみあたらず，乙たがっ てオートラジオグラフィと言えば写真乳剂を用いたもの と考光られている。このようなことから，写真感光材料 についての一般的な知識を得ておくことは，オートラジ オ゙グラフィの技術をさらに深く理解する上にも有効と考 えられるので,ここでは写真乳剤とその現像について簡 単な解説を試みた。

話の順序として，まず感光材料全般についての説明か ら入っていくことにする.

写真感光材料は一般に写真乳剤を適当な支持体,たと えばフィルムベース,ガラス, 紙などに数 に塗布したものである.この写真乳剂は，感光母体であ るハロゲン化銀の微細結晶をゼラチン中に多量に分散さ せたもので，正しくは賏濁液（suspension）と呼ばれる べきものであろらが，今な扔乳戍 (emulsion) と誤って 呼ばれている。このような写真乳剂層の一部に光を照射 し, これを顕微鏡で見ても, 外観上は未露光の部分と何
らの差異は認められない。しかし, これを現像液に浸漬 し，還元すると，光を照射した部分には，金属銀の微粒 子からなる黒化像を生じる. 一方, 未露光のハロゲン化

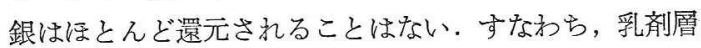
に光量子の多寡として与兄られた情報は，ハロゲン化銀

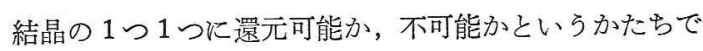
記録され，さらに現像によって銀粒子の分布として表示 される.したがって，銀粒子が微細であればあるほど， 画像の解像力は高くなると言える.これは一般感光材料 だけのことではなく，オートラジオグラフ用感光材料で も同様と考兄てよい。しかし皮肉なことに，微細な現像

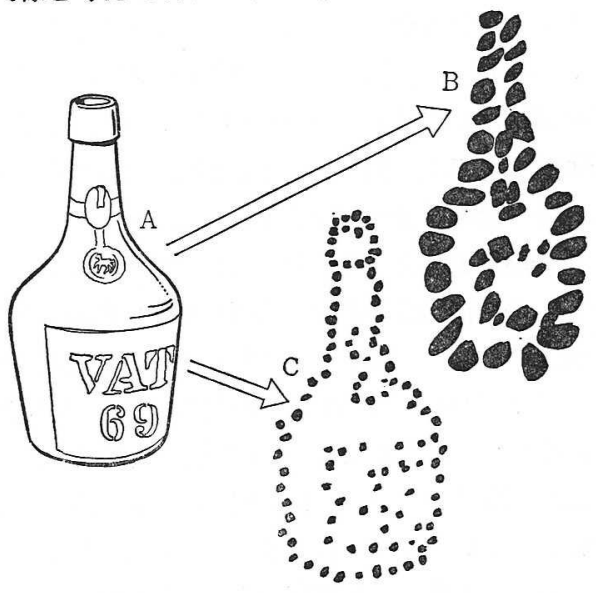

$3 \cdot 1$ 図 ハロゲン化銀結晶の大きさと,それによ って記録された画像の描写力との関係を示す Bは粗大結晶によるもの，Cは微結晶によるもの． 


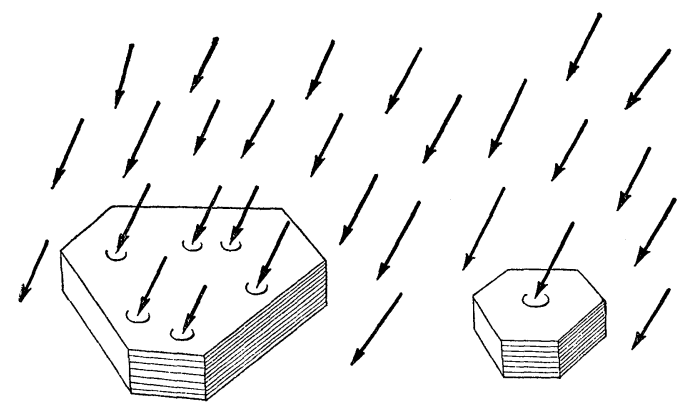

$3 \cdot 2$ 図大結晶ほど光量子に当たりやすい

銀を得るためにハロゲン化銀結晶を小さくすると，必然 的に，その感度が落ちる結果となる。このような結晶の 大きさと感度との相反性は, 次のように理解することが できよう、すなわち，各八ロゲン化銀結晶には，それが 現像可能となるため吸収しなければならない最少量の光 量子数が定まっており（この值は最高感度の乳剂でも結 晶 1 個当り $4 \sim 10$ 個と言われている), 結晶 1 個がこの 数デけの光量子を得るには，大きい結晶のほうが小さい ものより少ない露光時間で充分であるとして理解できる。 このことは, 雨中の石について, 大きな石が小さい石よ り早く一定数の雨滴に当たることから容易に想像できる ところであろう．このようにみてくると，八ロゲン化銀 結晶の大きさや形態がかなり写真的性質に影響している ことがわかる.したがって，これらハロゲン化銀結晶が 乳剂製造過程でどのようにして作られるかを知ることも， 興味あるところであろう。

\section{ハロゲン化銀結晶の成長}

乳剂は，八ロゲン化アルカリと硝酸銀の溶液とをゼラ チンの存在下に混合することによって作られる，反応の 結果生じるハロゲン化銀は，その溶解度が低いところか ら（飽和溶液にして $1 l$ 当り塩化銀で $1.4 \mathrm{mg}$, 臭化銀 で $0.2 \mathrm{mg}$ である), きわめて微細な核となって分散す る。これらの核の粒径分布は必ずしも定まったものでは なく，再結晶現象により時間とともに変化するものと考 えてよい，この再結晶現象は, 粒径の小さい結晶の溶解 度犺，大きい結晶より高いことに基づく物質移動現象で ある. 事実，粒径が $0.1 \mu$ 以下の場合，その溶解度は かなり增するのとみなしてょく, 微粒子は溶解して大粒 子の上に析出する.このようにして微粒子は次第に消光 平均粒径は大きいほうへと移動する。このような再結晶 現象は，八ロゲン化銀の溶解度を全体潧すことによっ てさらに顕著にみられるが，その一例としてのアンモニ ア（塩化銀，臭化銀を溶解する）の添加は, 直径 $1 \mu$

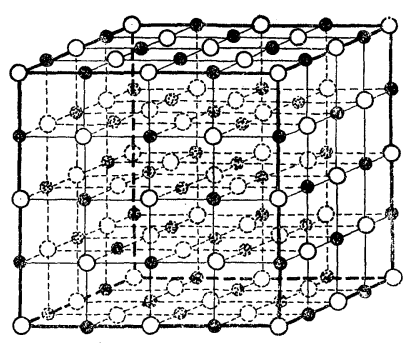

3.3 図 臭化銀結晶の立方格子

黑い円は銀イオンを，白い円は臭素イオンを表わす。格子 間隔は約 $5.8 \AA$ である. 正規の結晶はこの型と相似の立方 体か正八面体をなしているが，一般の写真乳剂中にはああり 見あたらず，ほとんぞが双晶棈造をるつ、オートラジオグラ フ用感光材料のなかには，立方体や正八面体をなしているも のもある (p. 109 カット写真参照).

前後の大粒子乳剤の製造技術として利用されている手法 である。

臭化銀，程化銀の結晶は，臭素イオン（塩素イオン） と銀イオンとが交互に立方格子点を占める，いわゆる食 塩型立方晶である。このような立方晶が成長する際には, 通常气の外形は立方体かまた性正八面体をとるのが普通 である．事実，臭化銀の場合，ある条件下で製造した乳 剤はこのような形態を持った結晶からできている。とく にオートラジオグラフィ用の乳剂は, 結晶の外形や粒径 を一定にし，乙か立体的にする必要から，この上らな 乳剤が用いられている。一方, 市販のネガフィルム用乳 剤では，平板状の三角や六角，または異方的形状をした 結晶からできていることが多い。このような結晶は，明 らかに特定な方向への成長が加速された結果できたもの である. 本来， 3 次元的に等価であるべき成長がこのよ らに異方的になること自体興味ある現象であるが，その 原因として，現在では，核生成期およ゙゙成長期での結晶 格子の不整が挙げられている. 確が, このような格子 の不整（ここでは双晶面）が一たび生ずると, 結晶表面 の特定方向に凹反を生じ，その幾何学的形状からこの部 分での表面核生成が他の平面上り速やかになると推測さ れる、したがって，その方向への急速な成長が起こるも のとして，この結晶の異方性が説明できる.

最近ふたたび注目をあびてきたマクロオートラジオグ ラフィに用いられる工業用 $\mathrm{X}$ 線フィルム・タイプNの乳 剂は，放射線に対する感度を高めるために，きわめて大 きな平板状結晶からできている。

\section{潜像形成効率}

前に述べたように，ある強さの光で照射した際，大き 
な結晶は小さな結晶より確かに早く一定数の（現像可能 にするに必要な最少限の）光量子を集めることができる. したがって, 従来より乳剤の感度をコントロールする一 手法として, 製造条件を变更し, 粒径を变えるというこ とが行なわれてきた。しかし，ここで注意したいことは， 粒径の大きな結晶すなわち感度の高い結晶ということに はならない, といらことである，これは，当たった光量 子が現像を誘発する核を作る効率，すなわち潜像形成効 率が，各結晶によって異なるからである，このことをさ らに深く理解するために, 潜像形成機構について考穴て みよう。

臭化銀の結晶は，前にも述べたように，立方格子点を 占める銀イオンと臭素イオンとによって構成されている. さらに厳密に言うならば, イオン半径の大きい臭素イオ ンは固く格子点に束縛され，動くことができないのに反 し，銀イオンの中には格子点より離脱し，格子間を自由 そ動ける，いわゆる格子間銀イオンが，わずかではある が存在している. 結晶が光量子を吸収すると, 臭素イオ ンは電子 1 個を離し, 自らは格子点の臭素原子となる. この原子はその原子半径からいって，とらてい格子間を 動くことはできない.しかし，隣接した格子点の臭素イ オンから電子 1 個を引きつけ臭素イオンとなり, 順次こ の過程をくり返すことによって，最初に電子を離脱させ た臭素原子（陽孔という）は，結晶中を表面に向かって 䔟動することができる.

光量子の吸収によって生じた電子と陽孔とは, ややも すれば再結合して元の臭素イオンになりがちである.こ れは最初の光分解反応の逆反応に当たるので, 潜像形成 効率々上げるには，光電子を陽孔との再結合を妨げるた めに両者を分離させることが必要である。この分離には, 乳剂製造工程中の化学熟成によって結晶表面に生じた銀, 硫化銀, 金などの核（感光核と呼ばれてきた）が有効に 働くとされているが，これら核の役割はまだ完全に判明 してはいない，ただ，現在のところ次の 2 つの作用があ ると考觉られている。すなわら，1つには陽孔のよき卜 ラップとなること, 他は光電子と格子間銀イオンとが結 合して銀原子学形成するに都合のよい場所となることで ある.もしも，このような結合反応が同じ場所でくり返 し行なわれたとすると（回数に相当する光量子の吸収に よって)，数原子からなる核 (潜像核) が形成される. そ して，これがある大きさにまで達すると安定となり，現 像の際, 結晶の還元を誘発する引き金の役割をはたすの である。

\section{露光した粒子の現像}

露光により電子顕徽鏡でも見兄ないほどの小さな潜像 核が一たび形成されたハロゲン化銀は，現像液中で還元 されて銀粒子となる.この析出銀の形状と大きさは, 露 光と現像時の条件によって変わる．最小で，かつ安定な 潜像核の構成銀原子は約 4 個と言われているが，このよ らな潜像核がハロゲン化銀結晶表面に 1 つでもあれば, この結晶全体を充分に現像可能，すなわら還元銀粒子に 変えることが可能である。 $0.1 \mu$ 程度の結晶 1 個には $10^{7}$ 〜 108 個の銀イオンが存在するから, これが全部銀に還 元されたものとすると, その增幅度は $10^{7} \sim 10^{8}$ という ことになる.もちろん, これは吸収された光量子 1 個が 潜像構成原子 1 個を形成するという最も効率の上い理想 的な状態を仮定しての場合であり，現実にはこれよりも 落ちることは予想されるところである。しかし，ともか く，このような高い增幅度をもっているといらことが， ハロゲン化銀乳剂をして現在な扮他の感光材料の追從を 感度の点で許さない理由である.

では，このような現像過程をもら少し詳しく述べてみ よう。まず現像はその機構上 2 通りにわけられ，それぞ れ物理現像 (physical development) と化学現像 (chemical development または direct development) と呼ば れている.

\section{物 理 現 像}

物理現像過程では, 現像液中の銀イオンが, 潜像核と 液相との境界面に析出する.もとより現像液中の銀イオ ンは現像直前に添加される場合もあれば，また現像液中 の助剤によって溶かされたハロゲン化銀から供給される こともある.

現像が始まると潜像核は急速にその大きさを増すとこ ろから，現像は一種の自触媒反応とみなすことができる. したがって，現像速度は核の表面積に比例するといって

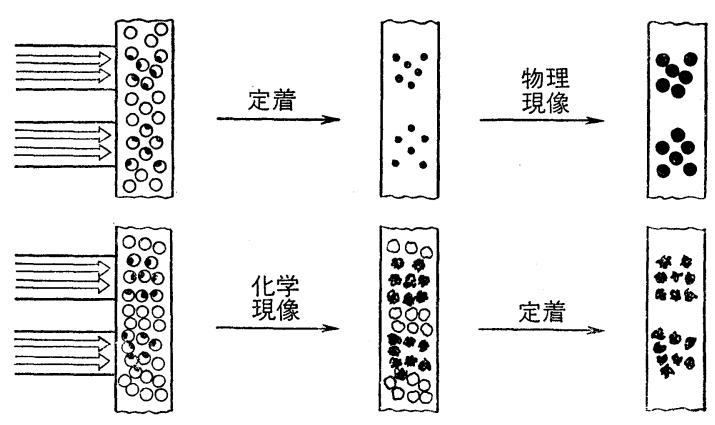

3.4 図 定着後の物理現像亡化学現像 
よいであろう，定着後の物理現像では，ハロゲン化銀結 晶は溶けて存在しないので，還元銀は潜像核（定着液に よっても溶けないで残存している）の上に，方向性を持 たずに析出する。したがって，現像銀粒子は梳とえど球 状に近い形状を持っている. それに反し, 定着前の物理 現像では, 定着後の物理現像と, これから述べる化学現 像とを合わせた様相を示す. 現像開始直後は化学現像に も似たフィラメント状の銀粒子の成長がみられるが，後 半になると八ロゲン化銀が銀核の近くに溶け出してくる ので, 銀核は等方的に成長する. その結果, 析出した銀 の形状は完全な球でもなくなたフィラメントでもない， その中間の太い棒状となる。

\section{化学現 像}

物理現像と異なり，化学現像はハロダン化銀溶媒のま ったくないところでも, 一種の電気化学的な過程によっ て起こる。おず，電子は現像主薬から潜像核に䔟される。

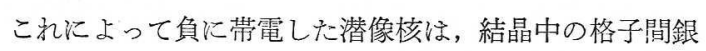
イオンをひき寄せる。これら格子間銀イオンは, 前にも 述へたように, 臭化銀結晶中に常に存在し, 格子点の銀 イオンとランダムな変換をくり返しながら熱的平衡を保 っているから, この結晶中の数は温度, 周团のイオン濃 度などによって常時一定に保たれる。

これらの格子間銀イオンと電子とは, 結唱と潜像核と の境界面で結合し，銀原子を生じる、この銀は結晶の内 部に成長することができないため, その結果, 潜像㤥は 新しい銀のために次第に押し出されることとなる。これ がフィラメント状の現像銀である。

現像速度は非常に多くの因子に影響されるので一概に は論じられないが, 現像の初期段階では, 電子の授受が きわめて遅く, これが律速段階となっている. 現像速度 はフィラメントの長さ（すでに析出した銀の量と考えて

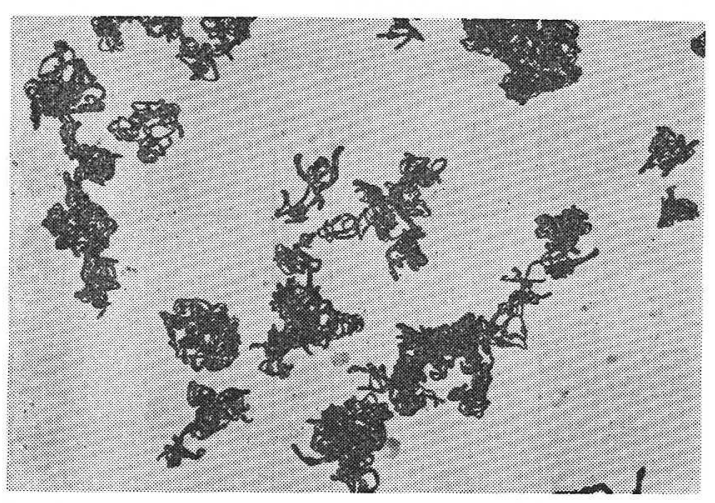

3.5 図 AR-10 (Kodak) の現像銀粒子

$(\times 11,700)$
よい）が增すにつれて速くなるから，析出した全銀量は 現像時間とともに指数函数的に增加する.しかし，銀イ オンの潜像核境界への移動が律速機構となっているとき は，現像速度は銀イオン濃度に依存すると言ってょい。

現像液の $\mathrm{pH}$ がきわめて高い場合について考えてみる 之, 現像液から潜像核への電子の移動が非常に速くなっ ていることがわかる、したがって，ここでは全現像過程 を通じて, その進行速度は, 潜像核への現像液の拡散速 度によってコントロールされていると言えよう。

\section{現像 速 度}

乳剂膜の現像速度は，一般に，現像時間に対する写真 濃度の伸びを測定することで知ることができるが，これ は結晶 1 個 1 個の真の現像速度を表わしたものにはなら ない，両者の関係をさらにはっきりさせるために，次の 2つの極端な例を考光てみよう。まず最初の場合 (A) は, すべての結晶がみな同じ速度で現像されると仮定し よう。もし現像を初期段階で中止したら，もちろん，す べての粒子は一部現像されたままにされ, 完全に現像さ れたものは皆無となるはずである。この一部しか現像学 れない乳剂膜の写真濃度は, 個々の粒子の濃度の総和に なる.次に, 全濃度は現像畤間とともに增加するが,こ れは銀粒子の粒径が大きくなることによるもので，その 数が増えたことによるものではない。

2 番目の可能性 (B) として, 各結晶は一度現像が始 まるや否や急速に，から完全に現像されるものとする。 このような場合では, 乳荗膜の濃度上昇は現像銀粒子の 增加で表わされる.

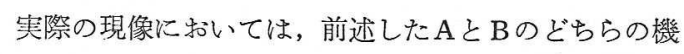
構が起こっているのであろらか. 低照度で長時間露光を 与えたフィルムについては, 通常Aの機構であると言わ れている。一般の撮影のように短時間露光の場合, また は $\beta$ 線照射による場合には, $\mathrm{B}$ の機構が支配的である。

\section{ハロゲン化銀結晶の感光機構}

ここで話を再びもどして，光や放射線に照射されたと きのハロゲン化銀結晶の挙動について述べたい.

光量子の吸収によって臭素イオンから飛び出した電子 は, より高いエネルギーレベルをで，いわゆる導電帯 (conduction band) まで上げられる. 導電帯にある電子 は自由に結晶内を動きまわり，それょりエネルギーの低 い個所, すなわち感光核 (銀や硫化銀の核で, そのエネ ルギーレベルは低くなっている）にとらえられる．電子 をとらえた感光核は負に带電するので, 易動性である格

化学上生物 
子間銀イオンを引きつけてこれを中和し，その場所に銀 原子をつくる.このようにして生じた銀原子は，さらに 電子のトラップ (trap) として働くから, この過程が光 の照射に応じてくり返され，感光核に銀が集積して,つ いには現像を誘発する核すなわち潜像核の大きさにまで 達する。

荷電粒子による潜像形成機構も, 光によるものとその 本質に拉いて变わりはない,すなわち, 荷電粒子が乳剂 中を走行するときに失われるェネルギーのらち，八ロゲ ン化銀中で失われたェネルギーによって生じた自由電子 (free electron) が，光量子の吸収によって生じた自由 電子と同じ働きをするからである。このような荷電粒子 による自由電子の発生は, 荷電粒子と乳剤構成原子の軌 道電子との静電的相互作用によって起こるものである.

この荷電粒子が乳剤中でどのようにしてェネルギーを 失っていくかについては, 前項 (本誌, Vol. 5, No.1, p. 54）を参照していただきたい。

これよりわかるよらに, 単位長さ当りのエネルギー損 失值は, 荷電粒子のエネルギーが低いほど大きい。した がって，いま $\beta$ 線を例にとると，低エネルギー成分ほど， また 1 本の $\beta$ 線についていえば終点に近いほど，単位長 さ当り,より多くのハロゲン化銀結晶を現像可能にする.

一般に, 荷電粒子によって, 結晶 1 個が現像可能にな るに要する自由電子の数は, 光の場合よりはるかに多い.
このことは, 荷電粒子の潜像形成効率が光に比べてかな り悪いことを示している．この理由については次のよう に考觉られる.すなわち, 荷電粒子のイオン化作用によ ってハロゲン化銀結晶中に生ずる電子は，ごく短い時間 $\left(10^{-13} \mathrm{sec}.\right)$ にきわめて多く，したがって格子間銀イ オンの供給がその易動度の小さいことから間に合わず， 大部分の電子は再結合してもとの状態にもどるからであ る.また，かろうじてできた潜像核にしても，現像時に 誘発する核として働く表面潜像のほかに, 現像には寄与 しない結晶内部の潜像すでできるからである。

終りにあたり，次のことを力説したい，写真乳剤がこ のような高感度を持ちらるということは, その勝れた增 幅機構である現像のおかげであり，その現像をひき起こ すむとはと言えば, 銀の数原子からできている潜像にほ かならない.このような数原子の銀が光量子の当たった 場所に限定されることなく結晶の特定の場所に集積する といらことは, 写真乳剂が半導体であるハロゲン化銀の 微結晶から構成されているからである.こら考えてくる と, 写真乳剂が粒子構造を持っているといらことが，そ のために, 現像後の粒状性や解像力の点で, 無粒子の感 光材料 (ジアゾタイプの感光材料, ラジカル反応利用の 感光材料，フォトクロミズム利用の感光材料など）に劣 るものがあるとは言え，重要な意味を持つことが牧わか りいただけたと思う。

\section{IV. マクロ（全身）オートラジオグラフィ}

\section{進 藤 英世, 中島 栄 - 三共株式会社中央研究所}

オートラジオグラフィは，i）検出感度が高く，ii） 標本と対比したアイソトープの分布図が得られること, iii）取扱いの簡便なこと,などの利点から生物学の分野 でも広く利用され, 最近はとくに物質代謝や薬理学的作 用の基礎研究には久かせない実験方法の 1 つとなってき ている.このらち肉眼で充分識別できるよらな乳剤膜の 黑化として記録する方法がマクロオートラジオグラフィ であり，顕微鏡で見た場合の乳剂膜中の現像銀粒子とし て検出する方法がミクロ拈よび電顕的オートラジオグラ フィである，したがってまた，この定義は組織一藏器の 集合体をマク口の視野で見ようとするか，あるいは細胞 単位で見ようとするかの区別と考えてもよい。ここに紹 介するのは，マウスなどの小動物をそのまま凍結し，ミ クロトームで全身の凍結切片を作り, 乾燥後 X線フィル
ムとコンタクトしてオートラジオグラムを得る，いわゆ る全身オートラジオグラフィである.

この凍結切片法は 1943 年, C.P. Leblond による凍 結乾燥による組織切片の作製を基礎とし, その後多くの 改良がなされた末，1956 年スウェーデンの S. Ul1berg により成熟マウスを液体空気中で凍結, $-10^{\circ} \mathrm{C}$ の冷凍 室で, いわゆる tape-section を作り, オートラジオグ ラムを得ることに成功したのが現在の方法である.

この方法の長所は，i）固定などによるアイソトープ あるいはラベル化合物の流出または移動を防ぐことがで きることである・たとえばラベル化合物を動物体内に投 与し, その分布, 経時変化などを観察する場合, 一般の 方法では固定, 染色が行なわれるが, その化合物が水溶 性または拡散性が強いときには流出してしまうおとれが 
ある，ii）全身の各臟器, 組織について全体的な分布が 一目でわかることである.多くの標本について比較する のと異なり，まったく同一条件下で視覚に訴える点は， 何と言っても強味である. iii) 時間的な分布，とくに短 時間の変化を捉えることができる点である. 各種の臓器 をそれぞれ分離して調べる場合には，同時的变化を見落 としてしまら抢それもあるし，とくに短時間の変化を見 ることはむずかしい，iv）たと党ば blood-brain barrier のような他の方法では検出の困難な微量の移行でも, 露 出時間を長くすることによって検出が可能である。また， v）原理的にはどんな種類のアイソトープでも使用でき ることも利点であろう。

一方，欠点というよりは注意すべき点としては，i） ${ }^{3} \mathrm{H}$ のようなきわめて低ェネルギーの $\beta$ 線放射体は，現 在市販の $X$ 線フィルムでは検出できない, 通常, 乳剤膜 $(20 \sim 25 \mu)$ の上に $1 \sim 2 \mu$ のゼラチンの保護層が塗布 されているが, ${ }^{3} \mathrm{H}$ の乳剤中の飛程は平均 $1 \mu$ 程度であ り，この保護層によってェネルギーの大部分が失われて しまうからである。したがって, 唯一の方法は原子核乳 剂を自分で塗布し，保護膜のない状態で使用することで ある。ii）逆に放射線のエネルギーが著しく高い場合に は解像力が劣る.たと党ば ${ }^{32} \mathrm{P},{ }^{90} \mathrm{Sr}$ などでは各部位の 輪郭がぼやけ，不鮮明な像しか得られない， iii）定量性 の点では当然劣り,オートラジオグラム相互の比較には, 同様のエネルギーを持つ標準線源をX線フィルムにあら かじめ塗布するか, あるいは条件，とくに切片の厚さ， 露出時間, ミクロトームナイフの角度などを厳密に等し くした上で行なうべきである.

\section{実 験の方法}

われわれる昨年来, 日本大学農獣医学部細谷英夫教授 の指導により, この方法を多くの薬物の吸収, 組織移行 の研究に応用して抢り, 以下, 実験方法を簡単に紹介す る.

1）アイソトープまたはラベル化合物の投与：最適投 与量は核種, 投与方法, 化合物の毒性や吸収性などによ って異なり一概には決められないが，筆者らの経験では ${ }^{35} \mathrm{~S},{ }^{14} \mathrm{C}$ 化合物では $0.1 \sim 0.5 \mu \mathrm{Ci} / \mathrm{g}$ 体重ぐらいが適当 である. また, ${ }^{60} \mathrm{Co}$ 化合物で $0.5 \mu \mathrm{Ci} / 20 \mathrm{~g},{ }^{3} \mathrm{H}$ 化合物 で $2 \mu \mathrm{Ci} / \mathrm{g}$ 以上の静脈内贽与で成功している. Ullberg の数多い報告からマウス静注の投与例を拾ってみると， ${ }^{35} \mathrm{~S}$-chloropromazine $1 \mu \mathrm{Ci} / \mathrm{g},{ }^{14} \mathrm{C}$-nicotine で $0.03 \mu$ $\mathrm{Ci} / \mathrm{g},{ }^{14} \mathrm{C}-\mathrm{DOPA} 9 \mu \mathrm{Ci} /$ mouse に対し ${ }^{3} \mathrm{H}-\mathrm{DOPA}$ では $400 \mu \mathrm{Ci} /$ mouse， ${ }^{137} \mathrm{Cs}$ 晾よび ${ }^{59} \mathrm{FeCl}_{3}$ それぞれ 0.2 お。
よび $0.5 \mu \mathrm{Ci} / \mathrm{g}, \quad \mathrm{NH}_{4}{ }^{82} \mathrm{Br}$ では $75 \mu \mathrm{Ci} /$ mouse, をた ${ }^{131} \mathrm{I} 1 \mu \mathrm{Ci} / \mathrm{g}$ に対し ${ }^{125} \mathrm{I}$ では $10 \mu \mathrm{Ci} / \mathrm{g}$, などが参考とな る.

2）凍結および固定：投与後, 所定の時間を経た後に 全身を凍結せしめるのであるが, 小動物は麻酔した後, アセトンーアルコール $(1: 1)$-ドライフイス $\left(-78^{\circ} \mathrm{C}\right)$ 中に投入して凍結せしめる.このとき動物の形を一定に するよう心がける.大動物の臟器について行なう場合に は，nーヘキサンードライアイスが好結果を与える。これ より以下の操作は, すべて $-16 \sim-20^{\circ} \mathrm{C}$ の冷凍室内で 行なら、まず涷結動物はアセトンを充分除いた後, 糊状 のメチルセルロースを敍りつけてミクロトーム台上に固 定し，ふたたび全体が充分凍結するのを待つ. 次に普通 のナイフであらかじめ目的とする切断面の近くまで荒け ずりを行ない（特定の贜器を目標とするのがよい）, 次 いでミクロトームナイフを用いて表面を整える.

3） Tape-sectioning: 切断面にスコッチテープ（マ ウスの場合, 幅 $5 \mathrm{~cm}$, 長さ $10 \mathrm{~cm}$ 程度の良質のもの) をはりつけ，その下側を $30 \mu(10 〜 50 \mu$ の間で可能 $)$ の厚さに切って行くと, テープに片面が付着したまま切 片をこわさずに切り取ることができる．ふたただテープ をはり，この操作をくり返して何枚かの切片を得る(4・1 図参照). 得られた切片はテープ粘着面を上にして並べ, $-16 \sim-20^{\circ} \mathrm{C}$ の冷涷室内に放置して乾燥させる. $30 \mu$

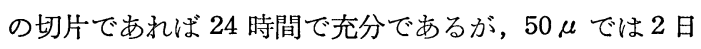
ほどかかる。

4）露出および現像: 完全に乾燥した後, 暗室で $\mathrm{X}$ 線 フィルム（サクラ Type N, またはフジ Type 200）に 密着させ, 暗所に放置して露光させる. 解像力を高める ためには,フィルムと切片とを直接密着させることが望 ましいが，いわゆる chemical ghost などでフィルムが 污染される怙それがあり，放射線の特質に応じた考慮が 必要である. 線放射体の場合には，切片をガラス板に 粘着面ではりつけ, テープ側をX線フィルムと密着して も良好なオートラジオグラムが得られる. ${ }^{3} \mathrm{H}$ の場合は, 先に述べたように乳剂保護膜のないX線フィルムによっ

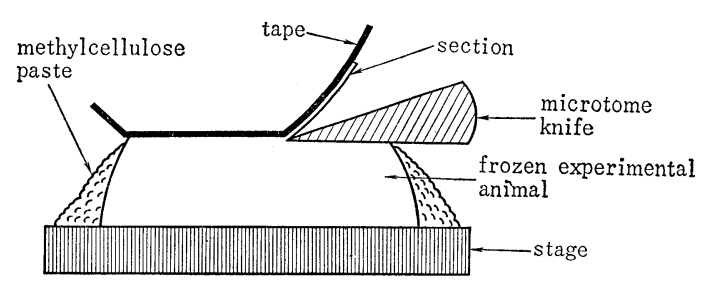

$4 \cdot 1$ 図 
てのみ可能であり, 解像力の高い写 真が得られるが，すりきず，指敉な どによる“かぶり”が扢こりやすく， 取り扱いに注意を要する。

露出時間もまた多くの条件により 左右され，一概に決められず，最低 数枚の切片を用意して経時的江現像 してみて最適の露出時間を求めるの がよく，実際にもこれ以外よい方法 はない，一例を挙げると ${ }^{35}$ S-thiamine $6 \mu \mathrm{Ci}$ 考マウスに静注, 30 分 以内では 3 日間, 72 時間後では 20 日間の露出で, 良好な黒化（黒化度 1.87 以下）を得た。

この方法はアイソトープを使える 低温室と大型のミクロトームのほか 汇特別な機器を必要としないが，ミ クロトームは一般に使用されている ユング型よりもライッの Type 1300 がよいこの型はメスを固定し，材 料を移動して切片を作製するから， マウスまたはラットのよらな大きな 材料でも比較的容易に操作すること ができる．普通のミクロトームでマ ウスなどを切ろらとしても，メスが 浮いてしまって䭾目である。次にテ ープであるが，国産品では $-10^{\circ} \mathrm{C}$ 以下では粘着性が低下するものが多 く,この点スコッチテープ No. 850 （工業用）が最もよい。低温室は常 時 $-10^{\circ} \mathrm{C}$ 以下に保つことが必要で， またアイントープを含む臟器末が飛 散し，污染する打それがあるから， 管理上とくに注意が必要である。

\section{応用の実例}

この方法によるオートラジオグラ フィの実例を揭げておく.4.2図A， B, C は ${ }^{35}$ S-thiamine 誘導体をマ ウスに $0.3 \mu \mathrm{Ci} / \mathrm{g}$ 静注し, それぞれ 12，48 拉よび 96 時間後の活涪正中 線に沿った切片から得たオートラジ オグラムである．全身のほとんどの 藏器が明膫に判別され， ${ }^{35} \mathrm{~S} の$ 分布

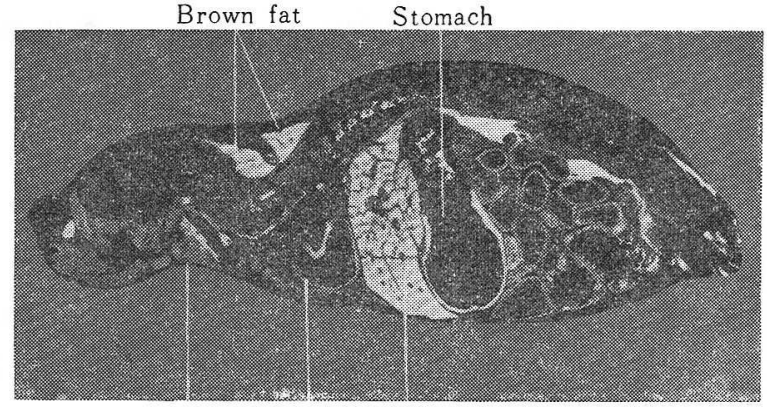

A Saliv. gland. Heart Liver

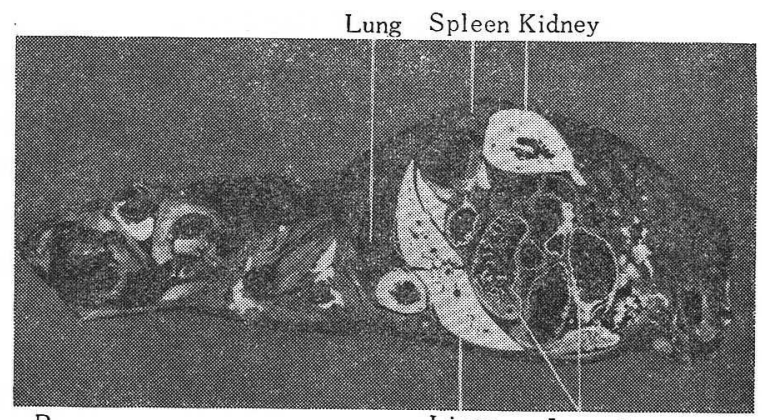

B

Liver Intestines

Brain Brown fat Diaphragm/ Kidney

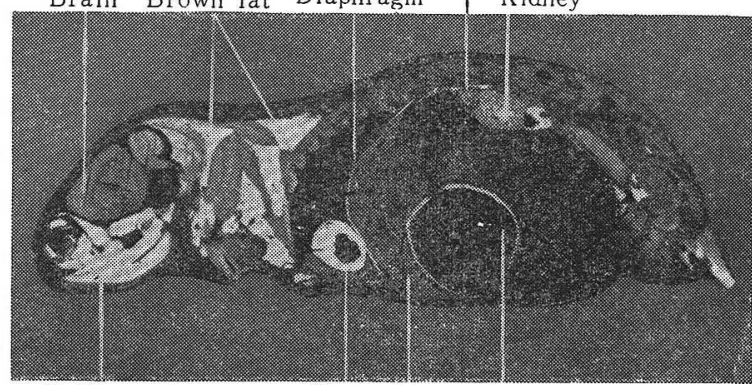

C Masseter muscle

Heart Liver Stomach

$4 \cdot 2$ 図

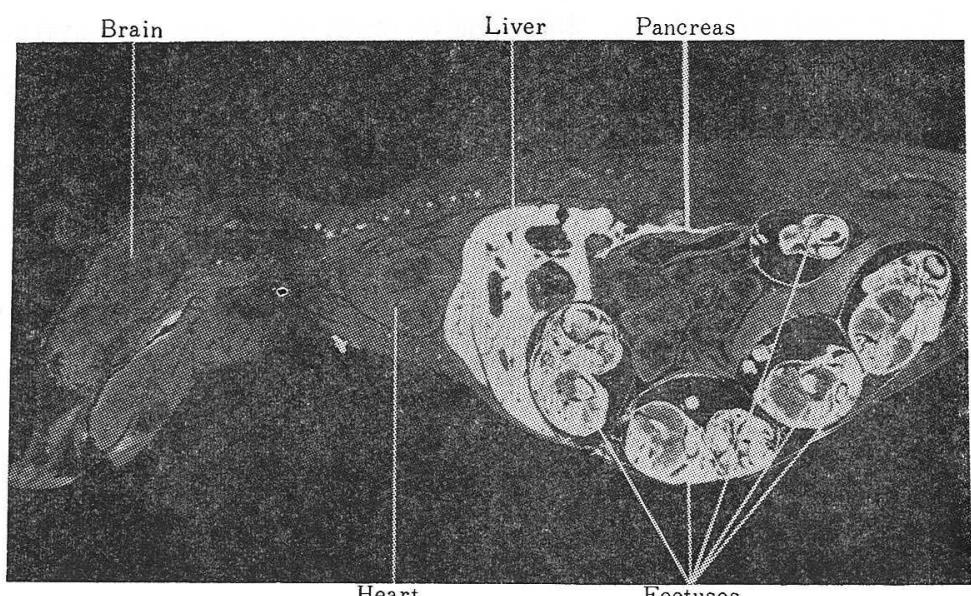

Heart

Foetuses

$4 \cdot 3$ 図

Vol. 5, No. 2 
がよくわかる、また，最初，肝および腎臟に移行したも のが次第に減少し, 一方, 脳, 心筋, 眼房などに次第に 增加する傾向が見られ，このようにして注入後の経時的 変化を観察することができる. 96 時間後, 脳, 咬筋, 褐色脂肪, 心筋, 胃壁, 横隔膜に ${ }^{35} \mathrm{~S}$ の貯留が鮮明で ある.4.3図は妊娠マウスの例で, ${ }^{14} \mathrm{C}$-ethionine を静 注後 4 時間のオートラジオグラムである (Hansson ら, 1961)。 ${ }^{14} \mathrm{C}$ 放射活性が母体に比へ，肝および膵臓を除け ば，胎児に最も高濃度に移行している.

この方法はマウスのほかに幼ラットでも可能であり， 最近では小鳥, 魚なども試みられている(細谷研究室). また，この方法は単に小動物全身の観察のみでなく，大 動物の一部ま快特定の臟器への広範な応用が可能であ る.たとえば山羊の乳房について $11 \times 14 \mathrm{~cm}$ の切片を 作り，乳房に塗布した ${ }^{35}$ S-penicillin が乳腺炎病巣部に 達しないことを確認した例 U11berg, 1958，1961）や, 猫の脳のオートラジオグラフィから ${ }^{14} \mathrm{C}$-nicotine の脳 内分布を調べた例（Appelgren ら，1962）などがよい 例である。

\section{結 語}

以上，マクロオートラジオグラフィの概略にンいて述 べたが, この方法の重要性は, わが国ではようやく最近 認識されてきたにすぎず，もっと普及され，応用範囲も 無限昿がることが期待される.1つの化合物の生物活 性を問題とする際などには必ずとられるべき方法である 之思う。また，解像力が充分よければ，数倍の写真拡大 で特定の臓器, 組織についてもかなりの情報を得ること ができ：ミクロ技よび電顕的オートラジオグラフィへ進 む前段階としても重要な方法であると思う.

最後にこの技術を教示され，本稿の校閲もいただいた 日本大学細谷英夫教授に深く感謝する.

\section{参考文献}

細谷英夫 : オートラジオグラフィによる実験動物体におけ る薬物の检察. 化学療法, No. 47, 11 13 (1966).

松岡理, 鹿島正俊: 凍結マクロオートラジオグラフ法とそ の応用. Radioisotopes, 15, 195 207 (1966).

中島栄一, 長尾荘七, 細谷英夫: O-Acetoglycoloyl-Sfuroylthiamine--35S 抢よび Thiamine- ${ }^{-35} \mathrm{~S}$ 組織内分布の全 身オートラジオグラフィ的検索. ビタミン, 33, 553 (1966).

(つづく)

\section{化学の空}

\section{プロスタグランジンの}

生合成と有機 合成

プロスタグランジンは羊の摂護腺や人間の精液に存在 し, 血圧の降下や平滑筋の収縮作用を示す因子として古 くから知られている. 本誌の用語解説欄 (Vol. 4, No.10) に紹介されたように，PGE $1, \mathrm{PGF}_{12}$ など同じ基本骨格を もつ数多くの同族体があり，動物の組織に広く分布して 重要な生理作用をはたしていると考兄られる。1957 年 に Bergström らが羊の摂護腺から $\mathrm{PGE}_{1}$ をとり出した のが最初で, 1962 年にその化学構造が (1) の上うに 決められた。くわしくは Samuelsson らの総説 [Ann. Rev. of Biochem., 34, 101 (1965); Angew.Chem. Intern. $E d ., 4,410(1965)]$ ]参照されたい。ここでは, その生合 成之有機合成について最近の報告を紹介することにする。

まず生合成であるが，PG の同族体はそれぞれ対応す る不飽和脂肪酸を前駆体としていることが容易に推定さ れ，それは ${ }^{3} \mathrm{H}$ を用いた実験により確かめら机ている。 たとえば， $\mathrm{PGE}_{1}$ (1) はアラキドン酸（2）から導かれ， る. その際に C-15，C-11 の水酸基と C-9 のケトン基: に3 個の酸素が入るが， ${ }^{18} \mathrm{O}$ を用いた研究で，これらは いずれも大気中の酸素分子が直接導入されることがわか った．とくに，C-11 とC-9 の酸素は同一の酸素分子に 由来することが，次の実験の結果明らかになっている [B. Samuelsson, J.Am.Chem.Soc., 87, 3011 (1965)].

まず, ${ }^{16} \mathrm{O}^{16} \mathrm{O}$ を $43 \%,{ }^{18} \mathrm{O}^{18} \mathrm{O} 56 \%,{ }^{16} \mathrm{O}^{18} \mathrm{O} 1 \%$ を含 む大気下で，（2）を摂護腺に加えて $\mathrm{PGE}_{1}$ を生合成さ せる.これに直ちに $\mathrm{NaBH}_{4}$ を加えて $\mathrm{PGE}_{1}$ の C-9 の ケトン基を水酸基に還元し，このケトンの酸素が水の酸 素原子と交換するのを防いだ後，メトキシル基として固 定する。これを酸化分解して（3）に導き，そのマスス ペクトルを測定したところ, 対照の（3）は C-9 と C-11. に酸素を持つフラグメントとして $\mathrm{m} / \mathrm{e} 343\left(\mathrm{M}-\mathrm{CH}_{3}\right)$, $313\left(\mathrm{M}-\mathrm{OC}_{2} \mathrm{H}_{5}\right), 297\left(\mathrm{M}-\mathrm{OC}_{2} \mathrm{H}_{5}-\mathrm{H}-\mathrm{CH}_{3}\right)$ のピークを示 した.これに対して ${ }^{18} \mathrm{O}$ のもとで生成した（3）では， これらピークのほかに, $\mathrm{m} / \mathrm{e} 343+4,313+4,297+4$ と,さらにきわめて弱い $\mathrm{m} / \mathrm{e} 343+2,313+2,297+2$ のピークを与えた.もし C-9 と C-11 の酸素が異なる 酸素分子からきたとすると, これらフラグメントの $\mathrm{m} / \mathrm{e}$ +2 と $\mathrm{m} / \mathrm{e}+4$ のピークの強度比は 1.5 になるはずで あるが, 観察された結果では 0.06〜0.08 ときわめて小 